\title{
- THE CULTURAL CHOICE: THE ARAB RENAISSANCE AND THE DISCOVERY OF WESTERN LITERATURE
}

\author{
AL SAFI HIND RAFEA ABALRASUL ${ }^{1}$ \\ University of Craiova \\ Craiova \\ Romania
}

U radu se opisuje arapska kulturna revolucija, poznatija kao al-Nahda, koja se odigrala tokom XIX i XX veka i tokom koje je veliki broj književnih dela evropskih autora preveden ili adaptiran na arapski jezik. Autor rada objašnjava koje su bile glavne faze u razvoju savremene arapske književnosti, počevši od al-Nahda, kulturne renesanse koja je započela krajem XIX veka. U radu se istražuju ekonomske i političke okolnosti koje su omogućile kulturni i kulturološki transfer tokom ove renesanse. Naglašava se važnost književnog prevođenja dela koja pripadaju Zapadnoj književnoj tradiciji, kao i opseg u kom su ta dela uticala na književnost(i) u arapskom svetu.

Ključne reči: adaptacija, al-Nahda, kulturni transfer, recepcija, prevođenje.

\section{INTRODUCTION}

The Napoleonic presence in Egypt and the entry into scene of General Nelson, burning the French ships and forcing Napoleon to return to France, aroused the Egyptian spirits with the epic utopia of an Arab nation that remembered the caliphate times in which the sun was "almost not hidden." This cultural renaissance also appealed to the foundational myths of a primal Islam although according to the times that ran from modernity. This movement is going to be known as 'Nahda' which literally means the awakening of the medieval dream following the Napoleonic enterprise:

Nahda is amplified by the multiplication of academic institutions (schools and universities) and by the translation movement which takes off from Egypt to spread across the region. In all countries, a growing number of intellectuals are working on

1 Kontakt podaci (Email): hegg4gg@gmail.com 
the study of the Arab language and culture, producing publications (dictionaries, encyclopaedias, novels, poems, newspapers, magazines) in a modernized Arabic language, nourished both by classical sources and by European cultures (Guidère 2012: 23, my translation).

Following the First World War, the Ottoman Empire was dismantled. The political revival is then moving towards a critique of foreign occupation and the development of Arab nationalism. Relying on the rediscovery of an idealized medieval past, but also on an Arab-centred vision of Islamic civilization, the new leaders draw the outlines of an Arab world identified by its language. The birth of the modern Arab states is thus part of a tension between a vision of "Western-style" progress and the claim of a properly Arab identity. Colonel Nasser's Egypt is the first Arab country to conceptualize the nationstate principle. The term nahda has been introduced into the daily vocabulary of Arabic/ Islamic political theory, meaning "rebirth", "awakening" and "Renaissance", and we will use it in Arabic, because the Nahda is a movement of thought in the Arabic language. It should be clarified that this same word would be the translation of the Renaissance that took place in southern Europe between the end of the fourteenth and mid-sixteenth centuries.

\section{FORERUNNERS AND THE DEVELOPMENT OF THE CONCEPT}

While the Nahda has allowed a lasting revival of Arab language and culture, the political modernization remains unfinished. Nasserism, like the regimes founded by the Baath Party in Syria and Iraq, have proven to be democratic failures. Pan-Arabism did not survive the conflicting interests of states. Economic problems, civil wars, the development of extremist ideologies continue to hinder this region of the world. Nevertheless, at the beginning of the twenty-first century, the "Arab Spring" seems to have revived the debate on the place and identity of Arab societies in the contemporary world.

One of the representatives of this reform movement is undoubtedly Rifa'a al-Tahtawi (رفاعة رافع الطهطاوي, 1801-1873) considered the father of modern Arab thought and founder of the cultural renaissance in Egypt. He was an education theoretician, political thinker, economist, man of letters as well as an excellent translator.

He graduated in 1823 at the prestigious university of Al-Azhar where he was later a professor. Between the late 20 s and early 30 s, he was part of the expedition to Paris of Mehmet Ali, ruler of Egypt at the time who thought that "the only way to catch up with Europe was to imitate it (Maalouf 2003: 76). For nine years, Tahtawi noticed the sociopolitical, cultural and economic structures of the French country after the French Revolution, realizing how outdated his country was (Chebel 2011: 129) of the banquet of civilization. On his return to Egypt, in 1835 he founded a School of Translators where Arabic, French, Turkish, Persian and Italian would be taught. He founded the first Egyptian newspaper Al-waqâ'i al-misriya (Egyptian events or events), later becoming his personal editor and director between 1842 and 1850. After an exile in Sudan, he was reinstated on the public scene where, in addition to resuming his educational and 
translation mission became the editor in chief of a new cultural supplement Rawdat alMadâris al-misriya (Garden of the Egyptian schools).

Tahtawi's reformist awakening in Egypt will lead to a collective political consciousness and a national feeling that will be globalized in the Islamic world. This archaeology of the Arab is to be theologized by rethinking the views towards the two instances of the political and the religious, that is, the role that both the ruler and the judge who knew Islamic law and the dialectical relationship that was going to play to establish between both poles of power.

After the loss of Granada, the Alhambra has been used as an object of worship and sublimation since the time of Chateaubriand and Washington Irving, attaining the status of a "paradise lost" - al firdaus al-mafqûd - as a biblical-Qur'anic analogy and hence al-Andalus began to be seen as a mythical and mystical event, a magical and alternative space that is frequently used in the context of crisis of coexistence and cultural and confessional tolerance. This common mental and conceptual framework will be reintroduced to the Islamic world in need of a neuronal and psychological revival to deal with the ruins of the Ottoman Empire and European power. Egyptian intellectuals, who were at the forefront unlike their other Arab compatriots, would see in this peculiar historical and legendary source the incentive to resurrect the memory of Islam and its most splendid era; and therefore, fix that common history and that standardized and homogenized past without obeying the geographical, ethnic and cultural nuances.

One of the most prominent of that proto-nationalist entourage is Ahmed Zaki Pasha (أحمد زكي بانشا, 1867-1934), son of a Moroccan and a Kurd, originally from Alexandria, who while still a student began his work as a translator for the provincial government of Ismailia. Thanks to his command of French, he devoted himself to journalistic activity in the Ministry of Interior, being a translator and editor of Al-waqấ'i al-misriya that Tahtawi had founded years before. Later he became a professor of translation and Arabic language at the Institut Français d'Archeologie Orientale in Cairo. During the First World War he was responsible for recoding the administrative procedures of Egypt as a British Protectorate. His invaluable work was recognized by being elected a member of L'Institut d'Égypte in Paris, the Royal Geographical Society and the Royal Asiatic Society in London.

The work of Zaki, a continuator of Tahtawi, outside of Egypt was crucial. He became a promoter who linked European Orientalists and Arabists with his Arab compatriots when they began participating in the International Congress of Orientalists such as Vienna in 1886. His work, Rihla ilô-I-Andalus (expedition in Andalusia) became a cultural springboard between Europe and the Arab and Islamic world.

Unlike Zaki, there was one of the top representatives of the Nahda who did not need to go abroad to excel and stand in a real lighthouse of the colonial Islamic world. This is Butrus al-Bustani (بطرس البستاني.1819-1883) of Syrian-Lebanese origin. He belonged to a Maronite Christian family and later converted to Protestantism due to the influence he received from the school of American missionaries. This conservative education allowed him to approach the Syriac and Latin languages that he perfected and dedicated himself to the study of Hebrew, Aramaic and Greek. Under the tutelage of this institution, he founded the first literary society of the Arab world Yâmi'at al- 
adab wa al-'ulum - Society of the arts and sciences - whose motto was "The love of the country is part of the faith" - hob al-watan mina-l-'îmân.

These three forerunners of the Nahda - al-Bustani, Tahtawi and Zaki - debated symbolically in this effervescent agora between Islam's longevity and its usefulness in the political and national affairs of the modernity, the need to emancipate from the 0ttomans but carrying out a diplomatic relationship - and not war or passionate rejection - with Europe. Paris, London and even New York - not forgetting other western capitals - and Cairo would be the destination of the generation of the next Nahda period.

At the beginning of the 20th century, when we speak of "Arabs", it is not only Bedouins or descendants of a tribe in the Arabian Peninsula, but also a national group united by its language. The word nahda is spreading, especially in Syrian-Lebanese intellectual circles, and is becoming historic. It expresses the idea of a civilizational revival and awakening of the Arabs as a nationality. In an Arab-centred vision of the Islamic civilization, largely borrowed from the Orientalists and the discourses of the ideologues of the end of the XIII century, it comes to designate a period of history whose beginning is symbolically fixed to the Bonaparte expedition in Egypt, a violent conquest, certainly, but which laid the seeds of civilization and encouraged the Arabs to make them fruitful. The concept of nahda then appears as the Arab national expression of the civilizing project of Enlightenment and colonial enterprises. It is also an acculturation of the 0ttoman reforms. The Arabs wish to be associated with it and to fully reap the benefits of civilization, of which Istanbul now appears to them a showcase, almost as much as Paris or London.

Along with that maintained altered literary vision of the East in general, Arab literature has been, with rare exceptions, the great unknown in Europe and not only among its writers. Knowledge of Arabic literature has been reduced to academic fields and specialists in the field, also very restricted, and although the work of translation has been increasing during the last decades, there has always been an enormous difficulty for its dissemination to a wider audience This difficulty has been alleviated, in part, after the awarding of the Nobel Prize for Literature to Naguib Mahfouz (1988), due to the interest shown by commercial publishers in publishing the translations of their novels and stories to different European languages; an interest that has been extended, in part, to the production of other contemporary Arab narrators. This fact, with being important, has not, however, managed to significantly increase the interest that literature so close to us deserves in many aspects and as dynamic as contemporary Arabic. Said Faiq, in his essay "The Cultural Context of Translating Arabic Literature", comments that, leaving aside the early novelistic tendencies in Arabic literature,

... the main achievement of Arab authors from the second half of the 19th century until the present day is the creation of a tradition of the Arabic novel. This statement implies, firstly, that the Arabic novelistic tradition is seen as a product of the nahda period, the phase of cultural reform under the influence of increasing contacts between Europe and the Arab world; and, secondly, that the Arabic novel is generally speaking derived from European models and European definitions of the genre. (Faiq 2004: 16) 
From a temporal point of view, a division, coarse without a doubt, but nevertheless revealing of the acceleration and amplification of the movement, makes it possible to distinguish within Arab cultural history three main moments. A good first half of the 19th century was characterized by the setting up, on a relatively continuous but ultimately rather slow basis, of initiatives as fundamental as essentially reserved for the infrastructure sector. The second period, that of the following two or three decades, introduces an important modification: the dynamic impelled from "from above", that is to say spheres of power, becomes more over time a push "from below", which is based on a slightly broader social base. However, it was not until the last two decades of the 19th century that the consequences of this long process acquired their full expression, thanks to the mobilization of a true value-producing intelligentsia which, in at least a few fields, found a certain response with fairly large sectors of an increasingly urban and educated population.

\section{THE ARABS' (RE)DISCOVERY OF THE WEST THROUGH TRANSLATION}

If, to paraphrase Kundera, the Western novel was born as "the echo of God's laughter," then the Arab novel was born from the Western novel, and it can be said that had it not been for the Western novel, the Arabic novel - with this great development in shapes and contents - would not have existed. At the beginning of the twentieth century, the Arab Renaissance movement began to give its first literary fruits. With the exception of some new and rising elites, the Arab people were living in a coma-like state. Their awareness of their present and future was very limited, if not nonexistent. The past was like an upright tent in the desert, where these peoples sought refuge from the bitter reality and forgot the injustices imposed on them by corrupt regimes and foreign powers that occupied their lands and wasted their dignity. But even this past, which these people were so proud of, and which they sang in their poems, was not clear for them, as they could not, in such a state of stagnation and absence, to distinguish the elements of power and the elements of weakness and the periods of bright and dark that permeated it. In the absence of modern universities and research centres and the lack of advanced knowledge, it was not easy for the enlightened elites, influenced by Western civilization as a whole, to mobilize these peoples and open their eyes to the issues of the present and the future. It was also not easy to remove the dust off the literary and intellectual heritage accumulated over centuries. For this reason, most of the great monuments created by the great Arab poets, writers and thinkers of different periods were almost absent from memory.

Arabic was the most difficult case. It is a language of simulation and impersonation and not a language of creativity. It is the language of inertia, degeneration, death and sick nostalgia. However, the literary situation began to improve gradually when the elites that were formed in Western universities returned home and were armed with some tools of modern knowledge and provided considerable knowledge of the different forms and currents literary and artistic that prevailed in the West at the time. The passion of Arab elites came in the art of storytelling and the story of the knowledge of some of its symbols studied in European universities on this art, as well as the result 
of completed translations, which transferred to Arabic - the language of Dād (لغة) (الضياد) - French, English and Russian literary and narrative stories. The reason for the designation of the Arabic language as "the language of Dād" is that it contains the letter Dōad (ض), representing a sound which is not found in any other language in the world. The various Arab tribes are famous for their ability to pronounce the letter "Dād" without difficulty, but people who are unfamiliar with the Arabic language find it very difficult to find a clear alternative that expresses this character in their languages.

Had it not been for these leaps, there would have been no novelists such as Mahmoud Taymour (1871-1930), Tawfiq al-Hakim (وحمود تيمور 1898-1987), Naguib Mahfouz (يحيى حقي 1911- 2006), Yahya in Egypt, Mikhail Naima (توفيق يوسف عواد) (تحفي (1889-1988) and Tawfiq Youssef Awad ميخائيل نعيمة) in Lebanon, Mahmoud Masadi (محمود المسعدي) and the Taht Es-Sour ("Under the Wall") Cafe group in Tunisia.

For example, in all the stories he wrote, Mahmoud Taimour tried hard to be an Egyptian Maupassant. Under the influence of the European writers, especially Ernst Renan, Taha Hussein (نطه حسي) wrote Al-Ayyam (الأيام, "The Days") and transported his readers back to his childhood and youth. And with an audience of great French novelists, Tawfiq al-Hakim wrote his masterpieces The Return of the Spirit (عودة الروح) 1933) and The Diary of a Country Prosecutor (يوميات نائب فى الأرياف 1933).

The translation movement began on the hands of Governor Muhammad Ali of Egypt while forming his army. He fostered the endeavour by importing the first printer in 1828 to Egypt (the second printer was brought later to Syria). Among the most prominent translators during that period was Rifa'a al-Tahtawi, who translated many scientific books for the army's use. Al-Tahtawi's influence is mostly recognized, however, in Talkhis al-Ibriz (Paris's Profile), in which he documented his visit to Paris. This book, written in a modern style, is an account of the political and social conditions in France during that time as perceived by the author. According to Richard Jacquemond,

In this sense, the history of Arab culture, from Tahtawi to the present, could be written through the prism of translation. It would show, for example, that in the 19th century, and into the first and second decades of the 20th century, literary translation ran along clearly different lines from pragmatic translation. Whereas the former began later and for a long time functioned 'ethnocentrically' early on, the latter transformed Arabic lexis and style. (Jacquemond 2004: 119)

Later, the Pen League of authors emerged and the works of these members, like Gibran and al-Rihani, quickly spread across the Middle East. Gibran not only published works in both Arabic and English, but also self-translated some of his works, such as Sand and Foam. Furthermore, other members of the league who contributed to the translation movement, pushed Arabic literature to new horizons. Starting with the adaptations of foreign plays, which began with Maroun al-Naqqash's adaptation of Moliere and Najib Haddad's translations of Corneille, Hugo, Dumas, and Shakespeare.

As the Arabic translation of modern Western short stories and novels grew, the art of storytelling began to develop at all levels. The Arabic language gradually abandoned the inherited rhetoric and rhetorical and verbal refinements, in favour of a vivid style able 
to capture the pulse of reality and draw its topography and dive into its depths. During the 1950s and 1960s, narrative and novel writing made a huge leap. The reason for this is that Arab storytellers and novelists have become more familiar with the modern methods and techniques in the West. They read the stories of the leading storytellers and novelists in Europe and America, such as Ernest Hemingway, William Faulkner, John Steinbeck, Virginia Woolf, James Joyce, Lawrence, Henry Miller, and others. Even Naguib Mahfouz himself - who thought, after completing his Cairo Trilogy (ثلاثية القاهرة) 195667 ) that he achieved what he wanted - began, after a long meditation period, to use modern techniques. This is evident in most of the works written in the 1960s such as The Thief and the Dogs (تحت المظلة: 1961), 1969). It is no exaggeration to say that the brilliant translation of Faulkner's novel The Sound and the Fury by Jabra Ibrahim Jabra (بردار ابراهيم جبرا (1920-1994) produced a real revolution in the Arab novel. Tayeb Saleh (الطيب صدالح) 1929-2009) demonstrated remarkable skill in the intelligent use of modern techniques in The Season of Migration to the North (موسم) الهجرة إلى الثمال Genet committees and the so-called Beatniks in America such as Jacques Kerouac had a significant influence on Moroccan novelists such as Mohamed Choukri (محمد شكري 1935-2003) and Mohamed Zafzaf (1945-2001).

He distinguishes two possible directions in the development of the novel: (1) as a continuation of the tradition "that ultimately reached its maturity in the 1960s", and (2) as a new genre in Arab and Iraqi literatures that came into existence primarily under the influence of the Western novel" (idem). The beginnings of the Iraqi novel are gallenerally identified with the works of Mahmud Ahmad al-Sayyid (مدود أحمد النديد) 1903-37), who wrote For the Sake of Marriage (الزواج (1921), The Fate of the Weak (الذكبات) 1922), and his more mature novel, Khalid Jalal (جلال خالد 1927). According to Haifa Zangana, since the publication of Khalid Jalal, fiction writing in Iraq

has been dominated by a sense of social and political commitment. Writers have refused to accept the bitter social and political reality and have striven, through the fictional world, to establish an imaginary reality. When they lack the skills or the artistic refinement necessary for writing fiction, they have sometimes succeeded only in recycling political and social reality" (Zangana 2007: x).

In the "Introduction" to the anthology Baghdad Noir (2018), Samuel Shimon comments on the contents of the Iraqi fiction writings which explore "Iraqi society and the matters of everyday life: love, revenge, romance, illness, and isolation," adopting "formal aspects like magical realism and existentialism" (Shimon 2018: 8-9), at the same time testifying to "the enduring resilience of the Iraqi spirit" under the circumstances in which "the rich traditions of intersecting cultures transcend the immediate political reality" (idem 11). At the level of content, the influence of the Western novel on the Arab novel was crucial. Thanks to this influence, Arab novelists have become bolder in dealing with forbidden and silent subjects, especially those related to religion, politics, gender and traditions. Thus, the Arabic novel became the art closest to the Arab reality in all its social, political, psychological and other manifestations. 
The translation of works of Western literature into Arabic started in Egypt, in the aftermath of Napoleon's campaign, when the country opened up to the Western world, allowing for contacts with cultures and civilizations other than the possessions of the Ottoman Empire. The Arabic translation movement began during Muhammad Ali Pasha's reign (1805-1848) while forming his army. It was during his reign that the first cultural missions abroad were held to train teachers in various scientific fields. Since the language of the Western sciences, which was essential for the development of his political projects, was foreign, Muhammad Ali gave translation a very important place; it is thanks to the translators that Egypt could maintain effective links with the Europe.

At the time of the nahda, Egypt experienced a great movement of translation and adaptation of Western writings into Arabic. First of all, scientific, political and administrative works for the state were translated, and later literary translation, which reached its peak in the first half of the twentieth century. The important translation effort allowed the Arabic language itself to become richer and simpler in order to express the changes that Egyptian society knew. Many neologisms were born, most of the time, inspired by French or English, in the scientific, technological and literary domains. The press also helped to give their first readers news, plays and novels translated into Arabic. The reception of these genres was done in part by the major newspapers which published them in the form of serials. The Western world occupied a prominent place in this new mode of expression through the influence of its political, economic and cultural models. This image of the West was served in particular by the "elite" press and the "European" press.

Most major newspapers, such as the famous al-Ahram ("The Pyramid"), founded in 1875 , began to publish Arabic translations of European fictional works as soon as they were first published. This was also the case of the al-Hilal newspaper ("The Crescent"), from its first publication in 1892. The Arab-speaking general public appreciated this kind of light and entertaining literature that the newspapers published in supplement. Journal editors also used translations of Western works to attract readers, often making them appear on the front pages.

The process started and continued successfully with translations from French literature, beginning with the Arabic rendering of Fenelon's Les Aventures de Télémaque ("The Adventures of Telemachus", 1699), published by Rifa'a Rafi 'al-Tahtawi under the title of Mawaqi' al-aflak. waqây 'Tilimâk ("The position of the stars or the adventures of Telemachus"), in 1851. It was followed by Paul et Virginie ("Paul and Virginia", 1787) of Bernardin de Saint-Pierre, a novel translated and adapted in 1872 by Muhammad 'Uthman Jalal (1829-1898) who is also one of the first adapters of Racine and Molière in the Egyptian dialect, as Tartuffe adapted under the title of Cheick Matlouf in 1873. The novel Paul and Virginia was then translated in 1902 by the intellectual secularist SyroLebanese Farah Antun (1874-1922).

Another interesting example is the popularity of Chateaubriand's novella Atala (1801), translated under the same title by Gamil Nahla Mudawwar, in Beirut in 1882. Maroun Abboud translates Atala and René under the Arab title of Atala wa Rini, published in 1910. Mustapha Lutfi al-Manfaluti adapted it under the title Al-Shuhada ("The Martyrs") and inserted it in his collection of novels adapted in the form of news 
and entitled al-Abarat ("The Tears") in 1915. Al-Manfaluti did not only bring back the French works by retranslating them, he also summarized some of them, his goal being to produce an entertaining and easily accessible literature for the general public with a predilection for sad stories, as evidenced by the titles.

Finally, the works of Alexandre Dumas father and son are part of French writings translated into Arabic which continue to be reissued until today because they represent a romantic adventure literature highly appreciated by the Arab public. The characters of these novels resemble by their exploits and their code of honour the Arab horsemen that poetry and classical prose celebrate. The novel The Three Musketeers (1844) was translated by Nagib al-Haddad in 1888, under the title al-Fursân al-thalôta. The Count of Monte-Cristo (1845) was translated by Bishâra Shadîd in 1871 who gave him the title of Qissat al-Kunt du muntû Kristû. The novel by Alexandre Dumas Jr., La Dame aux camélias ("The Lady of the Camellias", 1848) which inspired many Arab authors, has several versions including that of al-Manfalûti who transformed the novel into a novel that he published in 1915 under the title The Victim in his collection al-'Abarât ("The Tears"). Tanyus 'Abduh, in a more faithful translation, published this work in 1918 under the title Dât al-Zahra al-baydố'.

Such work has been continued and expanded throughout the present century and, more importantly, it has been largely carried out by critics and intellectuals as Louis 'Awad (translator of Aeschylus, Horace, Shakespeare or Shelley), and relevant writers such as Salama Musa (translator of Darwin), Taha Hussein (translator of Aeschylus, Sophocles and Gide), Rashad Rushdi (translator of Marlowe and Gogol), Shukri Ayyad (who translated from Russian literature and edited the medieval Arabic version of Aristotle's Poetics) or Edouard al-Jarrat (who translated Tolstoy's War and Peace).

The translation of more than 2000 scientific works was carried out through the Translation School founded by Tahtawi. In Beirut, the University of San José was created by the Jesuits in 1881 and the American University in 1886 that served as diplomatic, informative and cultural links between Europe and the contemporary Arab world. Marun Naqqas (1817-1885) had travelled to Italy, where he could enjoy Greek opera and drama, and introduced the dramatic genre to the Arab world which would later be adopted by Tawfiq al-Hakim in his Shahrazad (1934), inspired by The Thousand and One Nights. The novel as a genre was also developed by Salim al-Bustani with his Zenobia, consolidating itself in the contemporary Arab literary tradition.

However, the most recognized Arab writers abroad are Taha Hussein, professor at the new University of Cairo, and Gibran Khalil Gibran who, in the United States - together with his friend Mikhail Naima - created the figure of the greatest Arab intellectual of all time.

The knowledge, therefore, of the European narrative by the Egyptian writers is undeniable, as can the concrete and direct influence that a particular European author may have exerted in the production of a specific Egyptian writer, especially in the period between the end of the 19th century and the beginning of the 20th. As for the later decades of this century, there are numerous studies devoted to European sources or influences: Taha Hussein's works on Nietzsche or Bergson, Tawfīq al-Hakim's studies on Pirandello, Ibsen, Shaw, Brecht, Juan Ramón Jiménez and even Jacinto Grau or Unamuno, or Naguib Mahfouz's writings on Zola, Joyce, Maupassant, Kafka, Proust, 
Camus or Sartre. Other studies have highlighted the striking resemblances observed in the works of certain Egyptian narrators and those of other authors, without being easily explained based on prior knowledge.

\section{CONCLUSIONS}

Beyond the divergences on the diagnosis and the necessary remedies compared to a crisis of which all agree to recognize the gravity, all the actors who took part in the excitement of the Arab cultural scene at that time, especially during the last third of the 19th century, have one essential point in common, the evidence of which is such that it often passes unnoticed even though we can rightly consider it to be the main innovation brought by the Nahda. Their commitment on the cultural and intellectual scene reflects a real symbolic coup; the artist, the thinker, the intellectual of the Arab Renaissance is engaged in an educational project, in a reforming, even revolutionary action, relating to a societal aim for which thought, culture and art base their raison d'être on a legitimization of order no longer transcendental, nor even strictly aesthetic, but on the contrary political, in the etymological sense of the term, in relation to all that makes the lay reality of human communities.

During the Nahda - even from al-Bustani, Tahtawi and Zaki - the Arab world moved its impact, which generated the encounter with European civilization, to the growing production and dissemination of educational, scientific, literary and cultural content. The technical and scientific advances and the educational and cultural progress in which the European world was immersed were not going to go unnoticed by some Arab intellectuals who began to evoke those glorious times of Islam, building an atmosphere of empathy, acceptance and assimilation. Although we should not neglect the fact that this fascination for the European was not a pure or innocent act, but it showed the pragmatic will to try to transfer the enlightened splendour to the geography of the Arab world.

\section{REFERENCES}

Chebel, M. 2011. El islam. Historia y modernidad, 1ạ. ed., trad. Ana Millán Risco. Madrid: Paidós.

Faiq, S. 2004. The Cultural Context of Translating Arabic Literature. In S. Faiq (ed.) Cultural Encounters in Translation from Arabic. Clevedon, Buffalo, Toronto: Multilingual Matters, Ltd., 1-13.

Jacquemond, R. 2004. Towards an Economy and Poetics of Translation from and into Arabic. In S. Faiq (ed.) Cultural Encounters in Translation from Arabic. Clevedon, Buffalo, Toronto: Multilingual Matters, Ltd., 117-127.

Maalouf, A. 2003. In the Name of Identity: Violence and the Need to Belong, translated from the French by Barbara Bray. New York: Penguin Books.

Mathieu, G. 2012. Atlas des pays arabes: des révolutions à la démocratie? Paris: Flammarion. 
Sabry, H. 1993. The Genesis of Arabic Narrative Discourse: a Study in the Sociology of Modern Arabic Literature. London: Saqi Books.

Shimon, S. (ed.). 2018. Baghdad Noir. New York and Dublin: Akashic Books.

Zangana, H. 2007. Women on a Journey: Between Baghdad and London. Austin, Texas: The University of Texas at Austin.

\section{SUMMARY}

\section{THE CULTURAL CHOICE: THE ARAB RENAISSANCE AND THE DISCOVERY OF WESTERN LITERATURE}

During the $19^{\text {th }}$ and early $20^{\text {th }}$ centuries, the Arab Cultural Revolution known as al-Nahda brought about an intense work of translation into Arabic, and adaptation of the most representative works of some European authors. My contribution highlights the main stages in the development of modern Arab literature, starting with al-Nahda, the cultural Arab Renaissance of the late $19^{\text {th }}$ century. It investigates the economical and political background that made possible the cultural transfer brought out by the Renaissance. It stresses the importance of the literary translations from different Western literatures, and the extent to which they influenced the literatures in the Arab countries.

KEYWORDS: adaptation, al-Nahda, cultural transfer, reception, translation.

ARTICLE INF0:

Review article

Received: October 222019

Revised: January 292020

Accepted: January 302020 